\title{
Issues relating to classification of colluvial soils in young morainic areas (Chełmno and Brodnica Lake District, northern Poland)
}

\begin{abstract}
Colluvial soils (in Polish: gleby deluwialne) are an important part of the soil cover in young morainic landscapes of northern Poland. They evolved as a result of the accumulation of eroded material at the foot of the slopes and bottoms of closed depressions. The aim of this study was to determine the systematic position of colluvial soils commonly found in the Chełmno and Brodnica Lake District, northern Poland. Ten soil pits located in different types of landscapes were selected for testing soil properties. The colluvial material is characterized by diversified properties: thickness, particle-size distribution, organic carbon content, color, $\mathrm{pH}$, and base saturation. As a result, the investigated soils represent broad spectrum of typological units according to Polish Soil Classification (2011). Some of them contain epipedons mollic and meet the criteria of colluvial chernozemic soils. They were found mainly on buried black earths in areas with small slope inclinations. Many pedons contain pale colored acidic colluvial material with low base saturation and low organic carbon content and must be classified as other types: arenosols (in Polish: arenosole) or rusty soils (in Polish: gleby rdzawe). These soils occur mostly in areas with intensive relief and overlay the different soil types, including rusty soil and organic soils. They are formed as a result of soils lessivés and rusty soils truncation. An introduction of the additional units of "proper colluvial soils" which have epipedon ochric, and "rusty-colluvial soils" with endopedon sideric to the next edition of Polish Soil Classification would enable a more precise expression of the genesis of these soils in the type rank. Moreover, the definition of chernozemic colluvial soils could be extended to colluvial soils with umbric horizon. Classifying soils derived from colluvial material as soils of other types leads to the disappearance of this units on maps and underestimation of the impact of denudation on the soil cover.
\end{abstract}

Key words: anthropogenic denudation, soil erosion, colluvial soils, Polish Soil Classification

\section{INTRODUCTION}

Soils developed from the colluvial deposits (in Polish: osady deluwialne) are an important component of the soil cover in young morainic agricultural areas affected by human-induced erosion (Sinkiewicz 1998, Lang and Hönscheidt 1999, Smolska 2002, Bednarek and Szrejder 2004, Marcinek and Komisarek 2004, Podlasińska 2012, Kobierski 2013). Colluvial soils cover $12 \%$ of undulating morainic plateau of the Równina Wełtyńska region, NW Poland (Podlasiński 2013). In the hilly areas of the Brodnica Lake District, they share even more than $25 \%$ of total area due to the diverse relief (Świtoniak 2014). They are formed mainly in aggradation zones at the foot slopes (Sowiński et al. 2004a, Smólczyński and Orzechowski 2010, Wysocka-Czubaszek 2012) and in bottom part of depressions or kettle-holes (Frielinghaus and Vahrson 1998, Karasiewicz et al. 2014, Przewoźna 2012 , 2014). Since colluvial soils are the result of the accumulation of slope deposits they act as a kind of erosional geoarchive (Zolitschka et al. 2003, Leopold and Völkel 2007, Dotterweich 2008, Dreibrodt et al.
2010). Despite similar lithogenesis, these soils have strongly heterogeneous characteristics. Contrasted properties of the colluvial soils are connected with diversity of surface horizons of eroded soils and multiplicity of buried mineral and organic soils (Sowiński et al. 2004b, Orzechowski 2008, Paluszek and Żembrowski 2008, Smolska 2008, Świtoniak and Bednarek 2014). Different direction and rate of soilforming processes occurring in the deposited slope materials are additional factors affecting the heterogeneity of colluvial soils. In these soils biochemical weathering and concentration of pedogenic iron compounds is often observed (Orzechowski 2008, Jonczak and Kuczyńska 2008, Podlasiński 2013). Accumulation of humus substances under wet conditions is also very common (Jonczak and Kuczyńska 2008). Moreover, the occurrence of features resulting from the clay translocation was confirmed in some colluvial materials (Bieniek 1997).

In the fifth edition of Polish Soil Classification (PSC, 2011) only one type of colluvial soils within the chernozemic soil order can be distinguished. The surface horizon (epipedon) mollic is diagnostic horizon 
in these soils. However, as it was indicated by previous research (Świtoniak and Bednarek 2014), significant part of colluvial soils have sandy texture and acidic character so they can not meet the diagnostic criteria of mentioned epipedons.

The aim of this study was to determine the systematic position of soils developed from varied colluvial materials and attempt to identify solutions to classification problems relating to pedons which does not fulfil the criteria for distinguishing the chernozemic colluvial soils (in Polish: gleby deluwialne czarnoziemne).

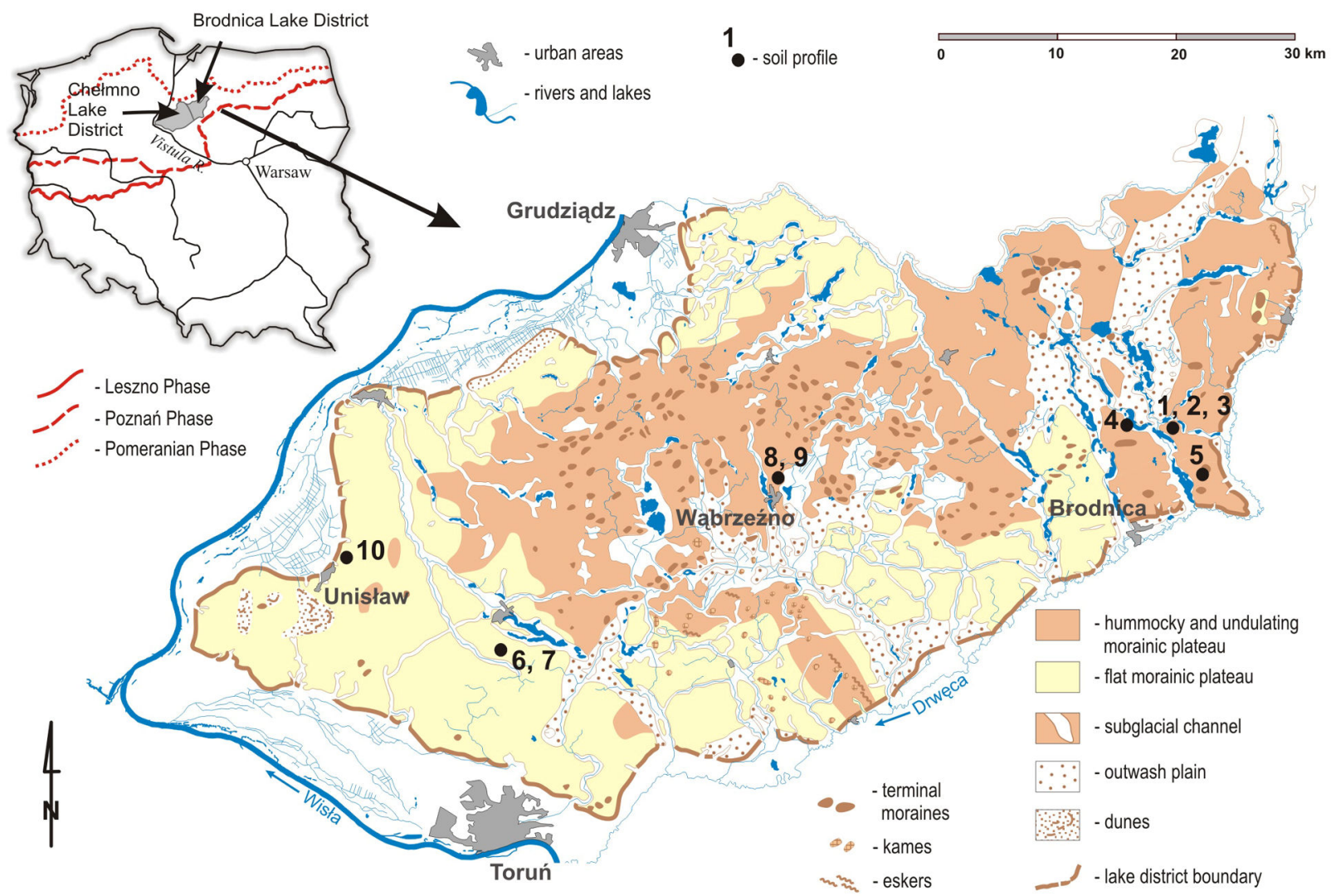

FIGURE 1. Localization of soil profiles

TABLE 1. Location of studied soils in young glacial landscapes

\section{MATERIALS AND METHODS}

The present study include ten soil profiles located in various types of young morainic landscapes of Chełmno and Brodnica Lake District, N Poland (Fig. 1, Table 1). Investigated pedons occur in depressions of different genesis or were in the lower parts of the slopes. All tested soils are currently (profiles 5-10) or in the recent past (profiles 1-4) used for agriculture purposes. As a criterion for distinguishing the colluvial soil, the minimum thickness of $30 \mathrm{~cm}$ of the colluvial 
sediments was taken. If colluvium thickness ranged from 30 to $50 \mathrm{~cm}$, they had to have at least half the thickness of the solum of a buried soil (PSC 2011). In all described cases, the precise separation of the colluvial materials from surface horizons of buried soils was possible due to the presence of abrupt or clear boundary between them (Fig. 2).

The samples were collected from selected soil horizons. Standard soil analyses were performed using the methods as follows: total organic carbon (TOC) content - by sample oxidation in the mixture of $\mathrm{K}_{2} \mathrm{Cr}_{2} \mathrm{O}_{7}$ and $\mathrm{H}_{2} \mathrm{SO}_{4}$ with external heating; $\mathrm{CaCO}_{3}$ content - volumetric method; particle-size distribution - by pipette and sieve method; $\mathrm{pH}$ of soil-to-solution ratio of 1:2.5 using $1 \mathrm{M} \mathrm{KCl}$ and $\mathrm{H}_{2} \mathrm{O}$ as the suspension medium; hydrolytic acidity by leaching with ammonium acetate at $\mathrm{pH} 8.2$; exchangeable base cations by leaching with $1 \mathrm{M}$ ammonium acetate at $\mathrm{pH} 7.0$ (noncalcareous samples) and pH 8.2 (calcareous samples). Hydrolytic acidity and exchangeable base cation content were used to calculate the base saturation (BS). Color has been described according to Munsell Soil Colour Charts (2000). The symbols of soil horizons were given after Polish Soil Classification (PSC 2011) and WRB (IUSS 2014).
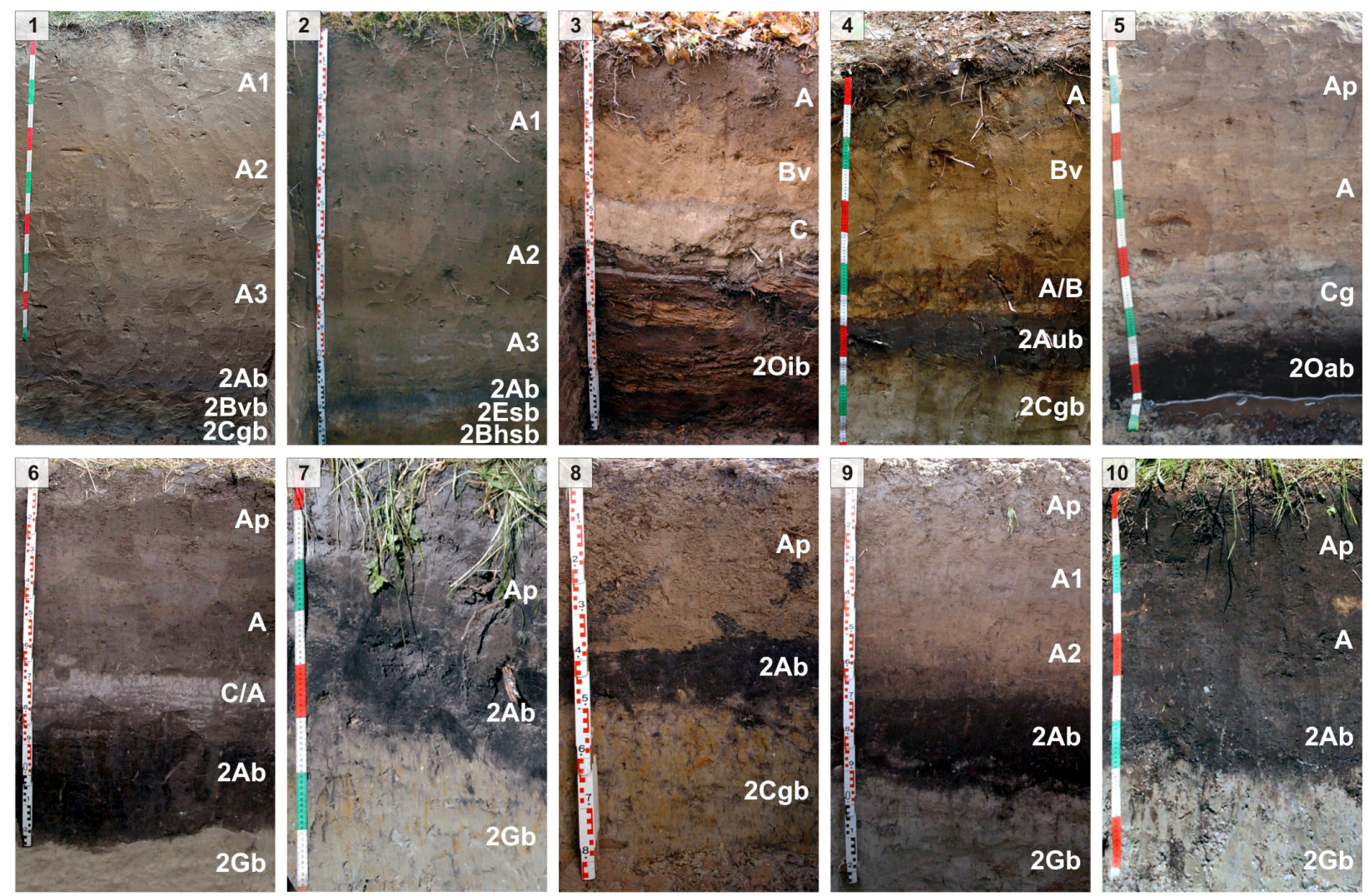

FIGURE 2. Morphology of investigated colluvial soils

\section{RESULTS}

The analyzed pedons are characterized by significant diversity of basic properties. The colluvial material has sandy (sand, weak loamy sand, and loamy sand) texture (Table 2) in profiles 1-4 localized in Brodnica Lake District. The rusty soils (in Polish: gleby rdzawe) and soil lessivés (in Polish: gleby płowe) developed from ablation sands and located at local elevations are the main source of mentioned colluvium (profiles $1-3)$. In the profile 4 colluvial deposits originated from rusty soils derived from subglacial, fluvioglacial sands. In the other six profiles (5-10), the colluvium is richer in clay fraction and represents several textural classes of loam or silt (Table 2). In their surroundings, on higher elevations, occur black earths (in Polish: czarne ziemie) or soil lessivés (in Polish: gleby płowe) developed from glacial tills or fluvioglacial materials considerably more rich in clay fraction.

The granular or subangular structural aggregates dominate in the presented colluvial soils. Size classes of structure vary with the texture. In sandy materials aggregates are fine or very fine and weak. Medium and coarse size of aggregates are typical for loamy 


\begin{tabular}{|c|c|c|c|c|c|c|c|c|c|c|c|c|c|}
\hline \multirow[t]{2}{*}{ Horizon } & \multirow[t]{2}{*}{ Depth } & \multicolumn{2}{|c|}{ Color } & \multirow[t]{2}{*}{ Structure } & \multicolumn{3}{|c|}{ Fraction [\%] } & \multirow{2}{*}{$\begin{array}{l}\text { Textural } \\
\text { class } \\
\text {-[PTG } \\
2008]\end{array}$} & \multirow[t]{2}{*}{$\begin{array}{l}\text { TOC } \\
{\left[\mathrm{g}^{\circ} \mathrm{kg}^{-1}\right]}\end{array}$} & \multicolumn{2}{|l|}{$\mathrm{pH}$} & \multirow[t]{2}{*}{$\begin{array}{l}\mathrm{CaCO}_{3} \\
{\left[\mathrm{~g} \cdot \mathrm{kg}^{-1}\right]}\end{array}$} & \multirow[t]{2}{*}{$\begin{array}{l}\mathrm{BS} \\
{[\%]}\end{array}$} \\
\hline & & & wet & & $\begin{array}{l}2-0.05 \\
{[\mathrm{~mm}]}\end{array}$ & $\begin{array}{l}0.05-0.002 \\
{[\mathrm{~mm}]}\end{array}$ & $\begin{array}{l}<0.002 \\
{[\mathrm{~mm}]}\end{array}$ & & & $\mathrm{H}_{2} \mathrm{O}$ & $\mathrm{KCl}$ & & \\
\hline
\end{tabular}

Profile 1 - Arenosol on buried gleyed rusty soil (Arenosol na glebie rdzawej gruntowo-glejowej)

WRB - Dystric Sideralic Arenosol (Colluvic, Ochric)

\begin{tabular}{|c|c|c|c|c|c|c|c|c|c|c|c|c|c|}
\hline A1 & $0-40$ & 10 YR $6 / 2$ & 10YR 5/2 & $\mathrm{sa} / \mathrm{vf} / \mathrm{w}$ & 75 & 22 & 3 & LS & 5.2 & 5.1 & 4.5 & n.a. & 1 \\
\hline A2 & $40-65$ & $10 \mathrm{YR} 6 / 2$ & 10 YR $5 / 3$ & $\mathrm{sa} / \mathrm{vf} / \mathrm{w}$ & 85 & 13 & 2 & LS & 4.3 & 5.3 & 4.9 & n.a. & 2 \\
\hline A3 & $65-125$ & $10 \mathrm{YR} 6 / 2$ & $10 \mathrm{YR} 5 / 2$ & $\mathrm{sa} / \mathrm{vf} / \mathrm{w}$ & 85 & 10 & 5 & LS & 4.8 & 5.3 & 4.8 & n.a. & 1 \\
\hline $2 \mathrm{Ab}$ & $125-130$ & 10YR $6 / 1$ & $10 \mathrm{YR} 4 / 1$ & $\mathrm{sa} / \mathrm{vf} / \mathrm{w}$ & 76 & 21 & 3 & LS & 8.4 & 5.0 & 4.3 & n.a. & 1 \\
\hline $2 \mathrm{Bvb}$ & $130-140$ & $10 \mathrm{YR} 7 / 4$ & 10YR 6/6 & $\mathrm{sa} / \mathrm{vf} / \mathrm{w}$ & 87 & 11 & 2 & WLS & n.a. & 5.9 & 5.2 & n.a. & 2 \\
\hline $2 \mathrm{Cgb}$ & $140-(150)$ & $\begin{array}{l}\text { GLEY } 2 \\
8 / 5 B G\end{array}$ & $\begin{array}{l}\text { GLEY } 2 \\
6 / 5 B G\end{array}$ & $\mathrm{~s}$ & 88 & 11 & 1 & WLS & n.a. & 6.8 & 5.6 & 4 & 3 \\
\hline
\end{tabular}

Profile 2 - Arenosol on buried gleyed podzol (arenosol na glebie glejobielicowej)

Dystric Arenosol (Colluvic, Ochric)

\begin{tabular}{|c|c|c|c|c|c|c|c|c|c|c|c|c|c|}
\hline A1 & $0-50$ & 10YR 5/4 & 10YR 3/4 & $\mathrm{gr} / \mathrm{m} / \mathrm{mo}$ & 82 & 15 & 3 & LS & 6.7 & 5.3 & 4.3 & n.a. & 1 \\
\hline A2 & $50-80$ & 10YR 5.5/4 & 10YR 3.5/4 & $\mathrm{gr} / \mathrm{vf} / \mathrm{w}$ & 89 & 10 & 1 & WLS & 3.9 & 5.3 & 4.3 & n.a. & 1 \\
\hline A3 & $80-110$ & $10 \mathrm{YR} 5 / 3$ & 10YR 3/3 & $\mathrm{gr} / \mathrm{vf} / \mathrm{w}$ & 90 & 10 & 0 & $\mathrm{~S}$ & 3.9 & 5.6 & 4.5 & n.a. & 1 \\
\hline $2 \mathrm{Ab}$ & $110-120$ & 10YR 5.5/2 & 10YR 3/2 & $\mathrm{gr} / \mathrm{vf} / \mathrm{w}$ & 88 & 11 & 1 & WLS & 4.9 & 5.8 & 4.7 & n.a. & 2 \\
\hline 2Esb & $120-125$ & 10YR 6/3 & $10 Y R \quad 4 / 3$ & $\mathrm{~s}$ & 91 & 9 & 0 & S & 2.9 & 5.9 & 4.6 & n.a. & 3 \\
\hline 2Bhsb & $125-(170)$ & 10YR 7/6 & 10YR 5/6 & $\mathrm{s}$ & 90 & 10 & 0 & $\mathrm{~S}$ & 1.8 & 5.8 & 4.7 & n.a. & 2 \\
\hline
\end{tabular}

Profile 3 - Typical rusty soil on buried fibric peat soil (gleba rdzawa typowa na glebie torfowej fibrowej)

WRB - Brunic Umbrisol (Endoeutric, Epiarenic, Colluvic, Ruptic)

\begin{tabular}{|c|c|c|c|c|c|c|c|c|c|c|c|c|c|}
\hline A & $0-25$ & $10 \mathrm{YR} 5 / 3$ & $10 \mathrm{YR} 2 / 3$ & $\mathrm{gr} / \mathrm{f} / \mathrm{mo}$ & 82 & 18 & 0 & LS & 11.8 & 4.8 & 4.0 & n.a. & 1 \\
\hline $\mathrm{Bv}$ & $25-45$ & $10 \mathrm{YR} 5 / 5$ & $10 \mathrm{YR} 4 / 6$ & $\mathrm{gr} / \mathrm{vf} / \mathrm{w}$ & 89 & 9 & 2 & WLS & 1.5 & 7.4 & 6.5 & 1 & 4 \\
\hline $\mathrm{C}$ & $45-60$ & 10YR 6/3 & 10YR $3 / 3$ & $\mathrm{sa} / \mathrm{vf} / \mathrm{mo}$ & 33 & 65 & 2 & LSi & n.a. & 7.1 & 6.2 & 1 & 8 \\
\hline 2Oib & $60-(120)$ & 7.5 YR $3 / 4$ & 7.5YR $2 / 1$ & f & n.a. & n.a. & n.a. & n.a. & 541 & 4.7 & 3.9 & n.a. & n.a \\
\hline
\end{tabular}

Profile 4 - Typical rusty soil on buried muckous soil (gleba rdzawa na glebie murszastej)

WRB - Dystric Brunic Arenosol (Colluvic, Ruptic)

\begin{tabular}{|c|c|c|c|c|c|c|c|c|c|c|c|c|c|}
\hline A & $0-20$ & 10YR 5/2 & 10YR 4/2 & $\mathrm{gr} / \mathrm{vf} / \mathrm{w}$ & 88 & 8 & 4 & WLS & 12.9 & 4.9 & 4.1 & n.a. & 2 \\
\hline $\mathrm{Bv}$ & $20-65$ & 10YR 6/4 & 10YR 4/4 & $\mathrm{gr} / \mathrm{vf} / \mathrm{w}$ & 93 & 5 & 2 & $\mathrm{~S}$ & 2.4 & 5.2 & 4.4 & n.a. & 2 \\
\hline $\mathrm{A} / \mathrm{B}$ & $65-75$ & $10 \mathrm{YR} 4,5 / 2$ & 10YR 3/2 & $\mathrm{gr} / \mathrm{vf} / \mathrm{w}$ & 91 & 6 & 3 & WLS & 22.3 & 5.0 & 3.9 & n.a. & 3 \\
\hline $2 \mathrm{Aub}$ & $75-90$ & $2.5 \mathrm{Y} 4 / 1$ & $2.5 Y 2.5 / 1$ & $\mathrm{gr} / \mathrm{f} / \mathrm{w}$ & 90 & 4 & 6 & WLS & 28.9 & 5.3 & 3.9 & n.a. & 2 \\
\hline $2 \mathrm{Cg}$ & 90-(130) & $2.5 \mathrm{Y} 7 / 3$ & 2.5 Y $6 / 3$ & $\mathrm{~s}$ & 92 & 6 & 2 & $\mathrm{~S}$ & n.a. & 6.4 & 5.5 & n.a. & 4 \\
\hline
\end{tabular}

Profile 5 - Leached black earth on buried sapric peat soil (czarna ziemia wyługowana na glebie torfowej saprowej)

WRB - Endomollic Umbrisol (Endoeutric, Loamic, Aric, Colluvic)

\begin{tabular}{|c|c|c|c|c|c|c|c|c|c|c|c|c|c|}
\hline Ap & $0-50$ & 10 YR $5 / 3$ & 10YR $3 / 3$ & $\mathrm{sa} / \mathrm{c} / \mathrm{mo}$ & 63 & 23 & 14 & LL & 8.2 & 5.4 & 6.5 & n.a. & 4 \\
\hline A & $50-90$ & $2.5 Y 5 / 2$ & $2,5 Y 3 / 2$ & $\mathrm{sa} / \mathrm{c} / \mathrm{mo}$ & 62 & 27 & 11 & LL & 7.9 & 6.5 & 5.6 & n.a. & 5 \\
\hline $\mathrm{Cg}$ & $90-120$ & $5 Y 7 / 2$ & $5 Y$ 6/2 & $\mathrm{sa} / \mathrm{m} / \mathrm{mo}$ & 29 & 56 & 15 & $\mathrm{CSi}$ & 3.3 & 7.1 & 6.3 & 6 & 9 \\
\hline $2 \mathrm{Oab}$ & $120-(140)$ & $2.5 \mathrm{Y} 4 / 2$ & $2.5 \mathrm{Y} 2.5 / 1$ & $\mathrm{am}$ & n.a. & n.a. & n.a. & n.a. & 376 & 6.9 & 5.8 & n.a. & n.a \\
\hline
\end{tabular}


Profile 6 - Chernozemic colluvial soil on buried gleyed black earth (gleba deluwialna czarnoziemna na czarnej ziemi glejowej)

WRB - Chernic Phaeozem (Loamic, Colluvic, Ruptic)

\begin{tabular}{|c|c|c|c|c|c|c|c|c|c|c|c|c|c|}
\hline Ap & $0-50$ & 10 YR $5 / 2$ & 10YR $3 / 2$ & $\mathrm{gr} / \mathrm{m} / \mathrm{st}$ & 59 & 37 & 4 & SL & 10 & 6.3 & 5.2 & n.a. & 6 \\
\hline A & $50-65$ & $10 \mathrm{YR} 5 / 2$ & $10 \mathrm{YR} 3 / 2$ & $\mathrm{gr} / \mathrm{m} / \mathrm{st}$ & 54 & 44 & 2 & SL & 6 & 7.2 & 6 & 1 & 9 \\
\hline $\mathrm{C} / \mathrm{A}$ & $65-85$ & 10YR 7/1 & 10YR 5/1 & $\mathrm{gr} / \mathrm{f} / \mathrm{st}$ & 53 & 43 & 4 & SL & 2.1 & 7.5 & 6.2 & 1 & 9 \\
\hline $2 \mathrm{Ab}$ & $85-120$ & $10 \mathrm{YR} 4 / 2$ & 10 YR $2 / 2$ & $\mathrm{gr} / \mathrm{c} / \mathrm{st}$ & 49 & 43 & 8 & $\mathrm{~L}$ & 30 & 7.0 & 6.1 & 1 & 9 \\
\hline $2 \mathrm{~Gb}$ & $120-(140)$ & $5 Y 7 / 3$ & 5YR 5/3 & $\mathrm{s}$ & 87 & 13 & 0 & WLS & - & 7.4 & 5.9 & 1 & 9 \\
\hline
\end{tabular}

Profile 7 - Chernozemic colluvial soil on buried gleyed black earth (gleba deluwialna czarnoziemna na czarnej ziemi glejowej)

WRB - Gleyic Phaeozem (Loamic, Aric, Colluvic, Pachic, Ruptic)

\begin{tabular}{|c|c|c|c|c|c|c|c|c|c|c|c|c|c|}
\hline Ap & $0-30 / 35$ & 10YR 5/2 & $10 \mathrm{YR} 3 / 2$ & $\mathrm{gr} / \mathrm{m} / \mathrm{st}$ & 51 & 47 & 2 & SL & 8.3 & 5.6 & 4.9 & n.a. & 6 \\
\hline $2 \mathrm{Ab}$ & $30 / 35-50 / 60$ & $10 \mathrm{YR} 3 / 2$ & 10YR 2/1 & $\mathrm{sa} / \mathrm{c} / \mathrm{st}$ & 63 & 25 & 12 & LL & 19.7 & 5.4 & 4.7 & n.a. & 5 \\
\hline $2 \mathrm{~Gb}$ & $50 / 60-(100)$ & $5 Y$ 6/2 & $5 \mathrm{Y} 4 / 2$ & $\mathrm{sa} / \mathrm{vc} / \mathrm{st}$ & 63 & 22 & 15 & LL & n.o. & 6.3 & 5.4 & n.a. & 7 \\
\hline
\end{tabular}

Profile 8 - Chernozemic colluvial soil on buried typical black earth (gleba deluwialna czarnoziemna na czarnej ziemi typowej)

WRB - Gleyic Phaeozem (Loamic, Aric, Colluvic, Ruptic)

\begin{tabular}{|c|c|c|c|c|c|c|c|c|c|c|c|c|c|}
\hline Ap & $0-35$ & 10 YR $5 / 2$ & 10YR $3 / 2$ & $\mathrm{cl} / \mathrm{c} / \mathrm{t}$ & 60 & 27 & 13 & LL & 7.5 & 5.9 & 4.9 & n.a. & 68 \\
\hline $2 \mathrm{Ab}$ & $35-55$ & $2.5 Y 3.5 / 1$ & $2.5 \mathrm{Y} 2 / 1$ & $\mathrm{sa} / \mathrm{c} / \mathrm{t}$ & 61 & 30 & 9 & LL & 12.3 & 5.8 & 4.7 & n.a. & 55 \\
\hline $2 \mathrm{Cgb}$ & $55-(80)$ & $5 Y 5 / 4$ & $5 Y 4 / 4$ & $\mathrm{sa} / \mathrm{vc} / \mathrm{t}$ & 59 & 30 & 11 & LL & 0 & 6.1 & 4.8 & n.a. & 83 \\
\hline
\end{tabular}

Profile 9 - Chernozemic colluvial soil on buried gleyed black earth (gleba deluwialna czarnoziemna na czarnej ziemi glejowej)

WRB - Haplic Phaeozem (Loamic, Aric, Colluvic, Pachic, Ruptic)

\begin{tabular}{|c|c|c|c|c|c|c|c|c|c|c|c|c|c|}
\hline Ap & $0-45$ & $2.5 Y 5 / 3$ & $2.5 Y 3 / 3$ & $\mathrm{cl} / \mathrm{m} / \mathrm{st}$ & 57 & 35 & 8 & LL & 9.7 & 5.7 & 4.5 & n.a. & 57 \\
\hline A1 & $45-60$ & $2.5 Y 5 / 2$ & $2.5 Y 3 / 2$ & $\mathrm{sa} / \mathrm{m} / \mathrm{st}$ & 50 & 42 & 8 & $\mathrm{~L}$ & 8.3 & 6.2 & 5.0 & n.a. & 82 \\
\hline A2 & $60-70$ & $2.5 \mathrm{Y} 4 / 2$ & $2.5 Y 2 / 1$ & $\mathrm{sa} / \mathrm{m} / \mathrm{st}$ & 63 & 35 & 2 & LL & 13.0 & 6.3 & 5.2 & n.a. & 87 \\
\hline $2 \mathrm{Ab}$ & $70-95$ & $2.5 \mathrm{Y} 3.5 / 1$ & $5 Y 2 / 1$ & $\mathrm{sa} / \mathrm{f} / \mathrm{st}$ & 61 & 35 & 4 & LL & 13.5 & 6.8 & 5.6 & n.a. & 80 \\
\hline $2 \mathrm{~Gb}$ & $95-(130)$ & $5 Y 7 / 2$ & 5 YR $5 / 2$ & $\mathrm{sa} / \mathrm{vf} / \mathrm{st}$ & 40 & 47 & 13 & $\mathrm{~L}$ & n.o. & 7.3 & 5.8 & 2 & 97 \\
\hline
\end{tabular}

Profile 10 - Chernozemic colluvial soil on buried gleyed black earth (gleba deluwialna czarnoziemna na czarnej ziemi glejowej)

WRB - Gleyic Chernic Phaeozem (Loamic, Aric, Colluvic, Ruptic)

\begin{tabular}{|c|c|c|c|c|c|c|c|c|c|c|c|c|c|}
\hline Ap & $0-30$ & $10 \mathrm{YR} 3 / 2$ & 10YR 2/1 & $\mathrm{gr} / \mathrm{m} / \mathrm{st}$ & 49 & 47 & 4 & LL & 20.9 & 5.9 & 5.1 & n.a. & 73 \\
\hline A & $30-50$ & $10 \mathrm{YR} 3 / 2$ & 10YR 2/1 & $\mathrm{gr} / \mathrm{m} / \mathrm{st}$ & 50 & 43 & 7 & LL & 21.0 & 5.9 & 5.1 & n.a. & 75 \\
\hline $2 \mathrm{Ab}$ & $50-65$ & $5 Y 3 / 1$ & $5 Y 2 / 1$ & $\mathrm{gr} / \mathrm{c} / \mathrm{st}$ & 55 & 35 & 10 & LL & 21.6 & 6.2 & 5.3 & n.a. & 81 \\
\hline $2 \mathrm{~Gb}$ & $65-(105)$ & $5 Y 6 / 2$ & $5 Y 5 / 2$ & $\mathrm{sa} / \mathrm{c} / \mathrm{st}$ & 49 & 40 & 11 & $\mathrm{~L}$ & n.o. & 6.7 & 5.4 & n.a. & 9 \\
\hline
\end{tabular}

Textural class: S - sand (piasek luźny), WLS - weak loamy sand (piasek słabogliniasty), LS - loamy sand (piasek gliniasty), LSi - loamy silt (pył gliniasty), CSi - clay silt (pył ilasty), SL - sandy loam (glina piaszczysta), LL - light loam (glina lekka), L - loam (glina zwykła); Structure: cl - clods, sa - subangular, gr - granular, s - single grain, f - fibric, am - amorphous / vf - very fine, f - fine, $\mathrm{m}$ - medium, c - coarse $\mathrm{vc}$ - very coarse / w - weak, mo - moderate, st - strong 
colluvium. These aggregates have a much greater durability (Table 2).

A majority of the colluvial layers has the humic character but very often it is slightly expressed. The maximum content of organic carbon in these horizons is $22.3 \mathrm{~g} \cdot \mathrm{kg}^{-1}$ (Table 2). In most cases, they contain low amounts of TOC not exceeding $10 \mathrm{~g} \cdot \mathrm{kg}^{-1}$. Therefore, the relatively light (gray-brown or brown) color of the colluvial material is the result of low humus content. In contrast, the color of buried humus horizons is darker, making them easy to distinguish from each other (Fig. 2). Some colluvial horizons are almost completely devoid of humus. Instead of humic substances the iron coatings on the mineral grains typical for sideric $(\mathrm{Bv})$ horizons were found in two subsurface sandy colluvial horizons (profile 3 and 4).

The colluvial materials are generally free of carbonates. The soil reaction shows a significant variation from acidic, through slightly acidic to neutral. The lowest $\mathrm{pH}$ value was recorded in sandy colluvium (profile 4) accumulated in lower part of subglacial channel slope ( $\mathrm{pH}$ in $\mathrm{KCl}-3.9)$. High differentiation also concerns the base saturation that ranged from 14 to $98 \%$.

Buried epipedons are characterized by even greater heterogeneity in comparison with colluvial deposits. In two cases, immediately below the colluvium, slightly decomposed peat of fibric-type (profile 3) and moderately decomposed peat of sapric-type (Profil 5) occurs. The organic carbon content in these materials was 541 and $376 \mathrm{~g} \cdot \mathrm{kg}^{-1}$, respectively (Table 2). In profiles localized in Chełmno Lake District (profiles 6-10) buried humus horizons Ab have black color, significant content of TOC in excess of $10 \mathrm{~g} \cdot \mathrm{kg}^{-1}$, loamy texture, well developed aggregate structure, and high base saturation (above 50\%). In profile 4 muckous material (in Polish: materiał murszasty) rich in humic substances occurred at the surface of buried soil. The reaction of this material is strongly acidic, and the base saturation is very low. In the other two cases, (profile 1 and 2) buried Ab horizons have sandy texture, acid reaction, and contain low amount of TOC (8.4-4.9 $\left.\mathrm{g} \cdot \mathrm{kg}^{-1}\right)$. Parent materials of all buried soils are strongly influenced by ground water: capillary fringe mottling and redoximorphic features - gleyic mottles and Fe-Mn concentrations.

\section{DISCUSSION}

The basic criterion to classify soils derived from colluvial deposits as chernozemic colluvial soils (in Polish: gleby deluwialne czarnoziemne) is the presence of mollic epipedon (PSC 2011). Five pedons (profiles 6-10) have surface horizons that meet the criteria of mollic epipedon. Analyzed chernozemic colluvial soils are marked by dark color, higher content of humus $\left(>6 \mathrm{~g} \cdot \mathrm{kg}^{-1}\right)$, well developed aggregate structure, and high base saturation ( $>50 \%$ ) of slope deposits. The criterion of phosphorus content was not taken into account, because there was no clear impact of human activity in these soils in the form of accumulation of waste or other artifacts. The high content of humus and dark color are often associated with organic carbon accumulation caused by slow decay of grass vegetation roots. The process occurs in the high moisture conditions what is typical for lower parts of slopes (PSC 1989, 2011, Jonczak and Kuczyńska 2008). Nevertheless, humus substances in investigated colluvial materials have predominantly allochthonous origin and are related to humus horizons of eroded soil lessivés (in Polish: gleby płowe) and black earths (in Polish: czarne ziemie) located at higher positions. In all analyzed cases, the material has a loamy texture which favors the formation of stable humic-mineral complexes and accumulation of organic matter. At least partially allochthonous genesis of humic substances in chernozemic colluvial soils (PSC 1989 - in Polish: gleby deluwialne próchniczne) resulting from the black earth erosion have been described, inter alia, by Orzechowski (2008).

The chernozemic-type colluvia in the Chelmno Lake District are also enriched in organic matter coming from buried underneath black earths (in Polish: czarne ziemie). The material from the fossil mollic horizons was mixed with colluvium by plowing during the initial phase of colluvium accumulation. The presence of the colluvial deposits rich in TOC originating partly from buried black earths in Chełmno Lake District has already been stated by Szrejder (1998). According to her studies, properties of slope deposits are strongly modified by fossil soils and therefore buried soil should be taken under consideration in determining the systematic position of colluvial soil.

Chernozemic colluvial soils (in Polish: gleby deluwialne czarnoziemne) occur more often in areas with low slope inclination (Table 1). Small denivelations indicate the slow erosion processes which do not lead to total destruction of humus horizons of eroded soils and favor accumulation of colluvium relatively rich in humic substances (Jonczak and Kuczyńska 2008). Occurrence of the colluvial soils which contain high amounts of organic carbon in flat and gently undulated morainic landscapes of Sępopolska Plain (NE Poland) was described by Orzechowski (2008). High content of organic carbon was also found in slope deposits accumulated as a result of slow truncation of Luvisols in Czech Republic (Zádorová et al. 2014). 
Subtypes of chernozemic colluvial soils were determined based on mollic horizon thickness. If buried mollic horizons occur directly underneath the chernozemic-type colluvium, their combined thickness was considered (profiles 7-10). In pedons 7 and 8 this thickness did not exceeded $60 \mathrm{~cm}$, therefore the soils were classified as typical chernozemic colluvial soils (in Polish: gleby deluwialne czarnoziemne typowe). The other three profiles $(6,9,10)$ represent cumulative chernozemic colluvial soils (in Polish: gleby deluwialne czarnoziemne kumulacyjne) due to combined thickness of mollic horizon larger than $60 \mathrm{~cm}$.

Second group includes the pedons (profiles 1-4), which do not fulfill most of the criteria of chernozemic colluvial soils despite the considerable colluvium thickness (Table 3). The slope deposits have too bright color (chroma and value $>3$ moist or value $>5$ dry) and low base saturation $(<50 \%)$. In the first two profiles content of TOC is also insufficient $\left(<6 \mathrm{~g} \cdot \mathrm{kg}^{-1}\right)$. All these properties are associated with characteristics of eroded soils. Described colluvial material originates from strongly eroded soil lessivés (gleby płowe) in case of profile 1 and rusty soils (gleby rdzawe) in profiles 2, 3, 4. High inclination of the slopes led to the high rate of erosion. The colluvial material comes from sandy, acidic, and poor in humus ochric and sideric horizons of eroded rusty soils or luvic horizons of eroded soil lessivés (Świtoniak and Bednarek 2014, Świtoniak 2014). In this group of profiles, the colluvial materials have a sandy texture (sand, weak loamy sand, and loamy sand). Because these colluvial deposits are not influenced by groundwater, the sediments are prone to drying, leaching of nutrients by rainwater (endopercolative type of water regime), and acidification. Their bright color may result not only from a low content of humic substances. In the profiles 3 and 4 the content of organic matter is even higher than in the above-mentioned darker chernozemic colluvial soils. The difference in color is probably due to the higher share of fulvic acids in sandy and acidic colluvium. The dependence of fractional composition of humus from the source of colluvium was confirmed by studies carried out on Głubczyce Plateau, S Poland (Licznar et al. 1993). Humic acids fixed with $\mathrm{Ca}$ and non-siliceous forms of $\mathrm{R}_{2} \mathrm{O}_{3}$ dominated in chernozemic colluvial soils of this plateau. The fulvic acids prevailed in other colluvial materials (non chernozemic) originated from truncation of brown soils (gleby brunatne). The higher susceptibility to leaching of labile humic acids in sandy colluvium (compared with loamy slope deposits) has also been detected in soils of Ińskie Lake District, NW Poland (Giegużyńska 2002).
TABLE 3. Properties of colluvial material with respect to mollic horizon criteria

\begin{tabular}{|c|c|c|c|c|c|c|}
\hline \multirow{2}{*}{$\begin{array}{l}\text { Profile } \\
\text { No. }\end{array}$} & \multirow{2}{*}{$\begin{array}{l}\text { Colluvium } \\
\text { thickness }\end{array}$} & \multicolumn{5}{|c|}{ Criterion of mollic horizon } \\
\hline & & $\begin{array}{l}\text { aggregate } \\
\text { structure }\end{array}$ & color* & $\begin{array}{l}\text { TOC } \\
\geq 6 \mathrm{~g} \cdot \mathrm{kg}^{-1}\end{array}$ & $\mathrm{BS}>50 \%$ & $>25 \mathrm{~cm}$ \\
\hline 1 & 125 & + & - & - & - & + \\
\hline 2 & 110 & + & - & + & - & + \\
\hline 3 & 60 & + & - & + & - & + \\
\hline 4 & 75 & + & - & + & - & + \\
\hline 5 & 120 & + & + & + & - & + \\
\hline 6 & 85 & + & + & + & + & + \\
\hline 7 & $30 / 35$ & + & + & + & + & + \\
\hline 8 & 35 & + & + & + & + & + \\
\hline 9 & 70 & + & + & + & + & + \\
\hline 10 & 50 & + & + & + & + & + \\
\hline
\end{tabular}

+ fulfilled criterion, - not fulfilled criterion

$*$ Chroma and value $\leq 3$, moist; value $\leq 5$, dry.

In this study, the epipedons of buried soils had no significant impact on contemporary amount of organic carbon in colluvial material in pedons $1-3$. In two first cases the fossil humic horizons ochric $(2 \mathrm{Ab})$ have properties similar to overlying colluvium. Their mixing with slope deposits did not result in perceptible changes of humus content. In profile 3, the buried peat was not mixed with the colluvium. Although the soil is situated at the foot of the slopes used for agricultural purposes, it is covered with timber forest and has never been ploughed.

According to the current Polish Soil Classification (2011), colluvial soils which do not fulfil criteria of mollic horizon must be included to soil types other than chernozemic. In profiles 3 and 4, colluvial material meets the criteria of subsurface horizon sideric Bv. These soils were consequently classified as rusty soils (PSC 2011). Genesis of Bv horizons can be associated both with post-sedimentary processes of sesquioxides accumulation as well as redeposition of soil material originated from eroded older sideric horizons. In profiles 1 and 2 ochric horizons are the only diagnostic horizons to the depth of $120-130 \mathrm{~cm}$. Other diagnostic horizons of these pedons were not taken into account in the diagnosis of systematic position of colluvial soils because these horizons developed as parts of fossil soils and represent the relic features which occur in deeper parts of the profile. Due to the sandy texture (Table 2) and thickness of ochric horizons $>10 \mathrm{~cm}$ both soils meet the criteria of arenosols only. The colluvial materials in described two profiles can be influenced by in-situ accumulation of sesquioxides similarly to the profile 3 and 4 . The effects of this process, however, are macroscopically invisible due to the humus nature (dark gray color) of colluvium.

The last considered pedon (profile 5) represents a transitional form. The slope deposits in this profile 
have many characteristics of the chernozemic soils: loamy texture, well developed soil structure, high amount of organic carbon and dark color. However, low base saturation (Table 2) allows to classify colluvium as umbric horizon. In this soil, the strong influence of ground-water have also been observed in bottom part of the colluvium. The pedon was classified as leached black earth (czarna ziemia wyługowana).

Classifying pedons developed from colluvial materials the same way as other types causes a loss of important information about the genesis of these soils. It is included only in the rank of genus, which is ignored in many cartographic studies. It will result in underestimation of colluvial soil on the maps, which may in turn lead to an undervaluation of the impact of erosion processes on the formation of soil cover. This is especially disadvantageous, because due to the small areas of particular contours of colluvial soils they were already often overlooked in the previous cartographic works (Bieniek 1997). The creation of additional soil taxons - proper colluvial soils (in Polish: gleby deluwialne właściwe) and rusty-colluvial soils (in Polish: gleby rdzawo-deluwialne) would enable a more precise determination of their specificity at the soil type level. Proper colluvial soils should be positioned in the order 2 of weakly developed soils (PSC 2011). The presence of ochric horizon (profile 1 and 2) developed from colluvium can be taken into account as the main criterion used for classifying these colluvial soils. In the case of the analyzed profiles 5, they would be classified as typical proper colluvial soil (in Polish: gleby deluwialne właściwe typowe), The profile 4 would represent rusty-colluvial soils (in Polish: gleby rdzawo-deluwialne). This type should be added to order 4 of rustyzemic soil (in Polish gleby rdzawoziemne). Moreover, the definition of chernozemic colluvial soils could be extended to the possibility of classifying colluvial soils with umbric into this type (profiles 3 and 5). The necessity of creation of additional classification units relating to colluvial soils has already been reported by Podlasiński (2013). It should be emphasized that in the fourth edition of Polish Soil Classification (1989) colluvial soils were treated as the order within which three types were distinguished: proper, humous and brown deluvial (i.e. colluvial) soils. This gave the opportunity to differentiate between chernozemic colluvial soils rich in humus, proper colluvial soil characterized by lower accumulation of organic matter, and pedons with visible accumulation of sesquioxides and clay fraction (Bieniek 1997, Piaścik et al. 2001, Sowiński et al. 2004a,b, Orzechowski 2008, Paluszek and Żembrowski 2008).

\section{CONCLUSIONS}

1. High diversity of basic properties is characterized for the colluvial soils of the Chełmno and Brodnica Lake District, N Poland. They represent a broad spectrum of soils extending beyond order of chernozemic soils (PSC 2011).

2. The investigated chernozemic colluvial soils are the result of the accumulation of loamy and humus colluvium, deposited on the surface of black earths developed primarily within depressions in flat and undulating morainic plateaus.

3. A significant part of analyzed colluvium is sandy, acidic or contains low amounts of organic matter. They were formed as a result of severe erosion of coarse textured soil lessivés and rusty soils. Soils containing these slope deposits do not fulfil criteria of mollic horizon and must be classified as other types e.g. rusty soils (in Polish: gleby rdzawe), leached black earths (in Polish: czarne ziemie wyługowane) or arenosols (in Polish: arenosole).It is suggested to restore proper colluvial soil type (in Polish: gleby deluwialne właściwe) within the order of weakly developed soils (in Polish: gleby słabo ukształtowane). The presence of ochric horizon developed from colluvium could be taken into account as the main criterion used for distinguishing soils of this type.

4. The creation of the new type of rusty-colluvial soils (in Polish: gleby rdzawo-deluwialne) within the order of rustyzemic soils (in Polish: gleby rdzawoziemne) should be very useful in determining taxonomic position of colluvial soils with well-developed sideric horizon.

5. Definition of chernozemic colluvial soils could be extended to colluvial soils with umbric horizon.

\section{REFERENCES}

Bednarek R., Szrejder B., 2004. Soil cover structure of the representative catchment of Struga Toruńska river. [In:] Kejna M., Uscka J. [Eds.], Integrated monitoring of the natural environment Functioning and Monitoring of Geoecosystems in the Grooving Human Activity Conditions. State Inspectorate for Environmental Protection, NCU, Toruń: 243-250 (in Polish with English abstract).

Bieniek B., 1997. Properties and development of alluvial and deluvial soils of Mazurian Lake District. Acta Acad. Agricult. Tech. Olst., Agricultura, Supplementum B, 64, 80 pp. (in Polish).

Dotterweich M., 2008. The history of soil erosion and fluvial deposits in small catchments of central Europe: deciphering the long-term interaction between humans and the environment - a review, Geomorphology, 101: 192-208.

Dreibrodt S., Lubos C., Terhorst B., Damm B., Bork H.-R., 2010. Historical soil erosion by water in Germany: scales and archives, chronology, research perspectives, Quaternary International, 222: 80-95. 
Frielinghaus M., Vahrson W-G., 1998. Soil translocation by water erosion from agricultural cropland into wet depressions (morainic kettle holes), Soil \& Tilage Research, 46: 23-30.

Giegużyńska E., 2002. Studies on the diversity of fractional composition, structure and physico-chemical properties of humic acids in colluvial soils of catena Dłusko in Ińskie Lakeland. Ph.D. dissertation. Szczecin, AR, 167 pp. (in Polish).

IUSS Working Group WRB, 2014. World Reference Base for Soil Resources 2014.

International soil classification system for naming soils and creating legends for soil maps.

World Soil Resources Reports No. 106. FAO, Rome.

Jonczak J., Kuczyńska P., 2008. Controls on the development of soils in a erosional-denudational valley of Wieprza near Mazów and selected soil properties. Landform Analysis, 7: 6979 (in Polish with English abstract).

Karasiewicz M.T., Hulisz P., Noryśkiewicz A.M., Krześlak I., Świtoniak M., 2014. The record of hydroclimatic changes in the sediments of a kettle-hole in a young glacial landscape (north-central Poland), Quaternary International, 328-329: 264-276.

Kobierski M., 2013. Morphology, properties and mineralogical composition of eroded Luvisols in selected morainic areas of the Kujavian and Pomeranian Province. University of Technology and Life Sciences, Bydgoszcz. 121 pp. (in Polish with English abstract).

Lang A., Hönscheidt S., 1999. Age and source of soil erosion derived colluvial sediments at Vaihingen-Enz, Germany. Catena 38: 89-107.

Leopold M., Völkel J., 2007. Colluvium: definition, differentiation, and possible suitability for reconstructing Holocene climate data, Quaternary International, 162, 163: 133-140.

Licznar M., Drozd J., Licznar S.E., 1993. Qualitative and quantitative composition of humic substances in deluvial soils of Płaskowyż Głubczycki. Zesz. Probl. Post Nauk Rol., 411: 139147 (in Polish with English abstract).

Marcinek J., Komisarek J., 2004. Anthropogenic transformations of soils of Poznań Lakeland as a results of intensive agricultural farming. AR, Poznań. 118 pp. (in Polish with English abstract).

Munsell Soil Colour Charts, 2000. GreagMacbeth, New Windsor.

Orzechowski M., 2008. The properties of eroded and deluvial soils in the Mazurian Lakeland and the Sepopolska Plain. Rocz. Glebozn. 59. 3/4: 236-242. (in Polish with English abstract).

Paluszek J., Żembrowski W., 2008. Improvement of the soils exposed to erosion in a loessial landscape. Rozprawy i Monografie, 4, 164. 160 ss. (in Polish with English abstract).

Piaścik H., Sowiński P., Orzechowski M., Smólczyński S., 2001. Soil sequence in mid-moraine depression of young glacial landscape in the Mazurian Lakeland. Zesz. Pobl. Post. Nauk Roln. 476: 491-496 (in Polish with English abstract).

Podlasińska J., 2012. Differentiation and chemistry of bottom sedmiments of small water bodies in morainic landscape. West Pomeranian University of Technology, Szczecin. 112 ss. (in Polish with English abstract).

Podlasiński M., 2013. Denudation of anthropogenic impact on the diversity of soil cover and its spatial structure in the agricultural landscape of moraine. West Pomeranian University of Technology, Szczecin. 119 ss. (in Polish with English abstract).

Polish Soil Classification (Systematyka gleb Polski), 1989. Soil Science Annual 40, 3/4: 1-150.
Polish Soil Classification (Systematyka gleb Polski), 2011. Soil Science Annual 62(3): 1-193.

PTG, 2009. Particle size distribution and textural classes of soils and mineral materials - classification of Polish Society of Soil Sciences 2008. Roczn. Glebozn. 60 (2): 6-15 (in Polish with English abstract).

Przewoźna B., 2012. Transformations of soils as an effect of anthropogenic denudation interpreted on the base of agricultural map of soils, ortophotomaps and terrain research. Prace Komisji Krajobrazu Kulturowego PTG 16: 148-156 (in Polish with English abstract).

Przewoźna B., 2014. Changes of bulk density, air-water properties and morphology of soils in basins without outlets as an effect of erosion and anthropogenic denudation (a study from northwestern Poland). Soil Science and Plant Nutrition 60.1: 30-37.

Sinkiewicz M., 1998. The development of anthropogenic denudation in central part of Northern Poland. UMK, Toruń. 103 pp. (in Polish with English abstract).

Smolska E., 2002. The intensity of soil erosion in agricultural areas in North-Eastern Poland. Landf. Anal. 3: 25-33.

Smolska E., 2008. Assesment of soil erosion processes based on sedimentological analyses of contemporary deluvial sediments on the example of the Suwałki Lakeland. Przegląd Naukowy. Inżynieria i Kształtowanie Środowiska. 2(40): 202-212 (in Polish with English abstract).

Smólczyński S., Orzechowski M., 2010. Distribution of elements in soils of moraine landscape in Masurian Lakeland. J. Elementol. 15 (1): 177-188.

Sowiński P., Smólczyński S., Orzechowski M., 2004a. Soils of mid-moraine depressions as biogeochemical barriers in an agriculture landscape of Mazurian Lakeland. Roczn. Glebozn. 55 (2): 365-372 (in Polish with English abstract).

Sowiński P., Smólczyński S., Orzechowski M., 2004b. Wpływ rolniczego użytkowania na właściwości fizyczno-wodne gleb w katenie moreny dennej Pojezierza Mazurskiego. Annales UMCS, Sec. E, 59, 3: 1057-1064 (in Polish with English abstract).

Szrejder B., 1998. Some properties and taxonomic position of soils evolved as a result of anthropogenic denudation in Koniczynka on the Chełmno moraine plateau. Zesz. Probl. Post. Nauk Roln. 460: 499-511 (in Polish with English abstract).

Świtoniak M., 2014. Use of soil profile truncation to estimate influence of accelerated erosion on soil cover transformation in young morainic landscapes, North-Eastern Poland, Catena, 116: 173-184.

Świtoniak M., Bednarek R., 2014. Anthropogenic denudation. [in:] Anthropogenic transformations of soil cover of Brodnica Landscape Park.[eds.] Świtoniak M., Jankowski M., Bednarek R., Wydawnictwo Naukowe UMK, Toruń: 57-84 (in Polish).

Wysocka-Czubaszek A., 2012. Assessment of deluvial soils in the Narew river valley. Inżynieria Ekologiczna 29: 236-245 (in Polish with English abstract).

Zádorová T., Žížala D., Penížek V., Čejková Š., 2014. Relating Extent of Colluvial Soils to Topographic Derivatives and Soil Variables in a Luvisol Sub-Catchment, Central Bohemia, Czech Republic. Soil \& Water Res., 9 (2): 47-57.

Zolitschka B., Behre K-E., Schneider J., 2003. Human and climatic impact on the environment as derived from coluvial, fluvial and lacustrine archives-examples from the Bronze Age to the Migration period, Germany. Quaternary Science Reviews 22: 81-100. 


\section{Problemy klasyfikacji gleb deluwialnych obszarów młodoglacjalnych na przykladzie Pojezierza Chełmińskiego i Brodnickiego}

Streszczenie: Gleby deluwialne stanowią ważny element pokrywy glebowej krajobrazów młodoglacjalnych Polski północnej. Powstają one w wyniku akumulacji zerodowanego materiału u podnóży stoków i w dnach zagłębień bezodpływowych. Celem przeprowadzonych badań było określenie pozycji systematycznej gleb wykształconych z materiałów deluwialnych, występujących powszechnie na terenie Pojezierza Chełmińskiego i Brodnickiego. Do badań wytypowano 10 profili glebowych położonych w różnych typach krajobrazów. Deluwia, występujące na obszarze badań, charakteryzują się znacznym zróżnicowaniem podstawowych właściwości: miąższości, uziarnienia, zawartości węgla organicznego, barwy, odczynu lub stopnia wysycenia kompleksu sorpcyjnego kationami zasadowymi. W wyniku tego zróżnicowania, gleby wytworzone z materiału deluwialnego reprezentują szerokie spektrum typologiczne. Cześśc z nich zawiera epipedony mollic i spełnia kryteria wyróżniania gleb deluwialnych czarnoziemnych. Deluwia czarnoziemne występują przeważnie na kopalnych czarnych ziemiach w obszarach o małych deniwelacjach. Część badanych pedonów zawiera materiał deluwialny: o kwaśnym odczynie, niskim stopniu wysycenia kompleksu sorpcyjnego zasadami, niskiej zawartości węgla i jasnej barwie, przez co muszą być klasyfikowane jako jednostki innych typów: arenosole i gleby rdzawe. Gleby te występują przeważnie w obszarach o znacznych deniwelacjach, przykrywająjednostki różnego typu od gleb rdzawych po gleby organiczne i powstały w wyniku ogławiania gleb płowych i rdzawych. Wprowadzenie do Systematyki gleb Polski dodatkowych jednostek gleb deluwialnych właściwych, mających epipedony próchniczne ochric i gleb rdzawo-deluwialnych z endopedonami sideric, a także rozszerzenie definicji gleb deluwialnych czarnoziemnych o pedony z poziomem umbric umożliwiłoby bardziej precyzyjne wyrażanie genezy tych gleb. Klasyfikowanie gleb wytworzonych z materiału deluwialnego jako pedony innych typów prowadzi do pomijania gleb deluwialnych w opracowaniach kartograficznych i niedoszacowania wpływu denudacji na pokrywę glebową.

Słowa kluczowe: denudacja antropogeniczna, erozja gleb, gleby deluwialne, Systematyka gleb Polski 